\title{
Velocity Encoding Minimum Value
}

National Cancer Institute

\section{Source}

National Cancer Institute. Velocity Encoding Minimum Value. NCI Thesaurus. Code C69288.

The minimum acceptable encoded velocity. 